Florea : Jurnal Biologi dan Pembelajarannya, 8(2), 2021, 99-102

This is an open access article under the CC-BY-SA license (https://creativecommons.org/licenses/bysa/4.o/)ISSN 2355-6102(print), ISSN 2502-0404(online)

DOI : 10.25273/florea.v8i2.9226

\title{
IMPLEMENTASI AUGMENTED REALITY DENGAN MENGGUNAKAN VISUAL WIKU DALAM JENJANG PENDIDIKAN
}

\author{
Sukian Wilujeng ${ }^{1)}$ dan Hery Setiyawan ${ }^{1)}$ \\ 1,) Universitas Wijaya Kusuma Surabaya, Surabaya, Indonesia \\ Email: ${ }^{1)}$ wsukian@gmail.com
}

Diterima 28 Agustus 2021 disetujui 23 September 2021 diterbitkan 30 November 2021

\begin{abstract}
This study aims to determine the results of augmented reality trials using visual WIKU can be applied at the level of junior high school, high school, or S1 majoring in biology. The Method used in Phase 1 determines the level of the school, the determination of the school footprint is based on the content of learning media (content) that is in augmented reality using visual WIKU, namely subjects that explain the morphological structure of the Wijaya Kusuma flower. From the results of these considerations, three levels of schools were determined, namely junior high, high school and S1 biology majors as sampels from the trial. Stage 2 makes questionnaire, questionnaire is made so that it can know the response of students-students, to assess augmented reality using visual WIKU both in terms of the application interface and existing application content. The questionnaire is validated to parties who are competent in their fields. Phase 3 of data analysis, the results of the questionnaire data were analyzed both quantitatively and qualitatively, in order to obtain which level of school remained to apply augmented reality using this visual WIKU. From the results of this study it can be concluded that the level of junior high school education that gives good grades with a weight of 4 on augmented reality using visual WIKU, which means augmented reality using visual WIKU can be applied to junior high school education
\end{abstract}

Keywords: Implementation, AR, Visual Wiku, Educational Level

\section{PENDAHULUAN}

Di era globalisasi milenium saat ini, seorang pendidik dituntut berpikir kreatif dan inovatif, utuk mengkondisikan saat berlangsungnya proses belajar mengajar supaya tidak membosankan dan monoton. Banyak cara agar membuat pembelajaran menjadi lebih menyenangkan seperti penggunaan media pembelajaran, alat peraga ataupun menggunakan model pembelajaran yang inovatif.

Mengoptimalkan pembelajaran merupakan cita-cita dari semua pendidik. Salah satu cara yang di gunakan oleh seorang pendidik, dengan menfaatkan kecanggihan dari adanya smart phone android, sebagai media pembelajaran yang bisa menghidupkan suasana kelas yang menyenangkan bagi siswa pada waktu menerima pelajaran .
Smart phone android sekarang ini bukan merupakan barang mewah lagi, setiap siswa yang duduk di berbagi jenjang pendidikan apapun sudah mengenalnya.

Smart phone android ini merupakan salah satu teknologi multimedia yang bisa untuk mengoperasikan teknologi Augmed Reality (Supardi, 2011).

Augmented Reality menurut Azumi, 1997 merupakan gabungan obyek nyata dan virtual dalam lingkungan nyata, berjalan secara interaktif dalam waktu nyata dan ada integrasi antara obyek dalam tiga dimensi, yaitu obyek virtual yang diintegrasikan ke dalam dunia nyata.

Media pembelajaran merupakan ujung tombak dari proses belajar mengajar, supaya materi pelajaran muda untuk dipahami oleh seorang siswa. Media pembelajaran di samping untuk membantu 
pendidik dalam menjelaskan informasi tapi juga membuat peserta didik lebih tertarik dalam mengikuti pembelajaran. Augmented Reality menurut Alex, M dan Tonny, K, 2017 " merupakan salah satu teknologi di bidang multimedia yang dapat menggabungkan obyek digital ke dunia nyata

Manfaat Augmented Reality sebagai media pembelajarn, merupakan trobosan baru yang menghadirkan contoh-contoh seperti aslinya. Tidak hanya berupa gambar diam yang tidak bisa bergerak.

WIKU merupakan inisial dari hasil pikiran yang memadukan teknologi dengan memanfatkan Augmented Reality yang melewati berbagai proses untuk menghadirkan bagian demi bagian dari adanya bunga Wijaya Kusuma seperti aslinya.

Visual WIKU dibuat untuk menjawab tantangan tersebut, apakah dengan teknologi yang menggunakan Augmented Reality ini bisa menyampaikan materi yang tidak dapat dilihat di kelas, dihadirkan secara nyata seperti aslinya yang ada di alam.

Visual WIKU dengan menggunakan Augmented Reality ini perlu di uji cobakan terhadap siswa-siswa yang mempunyai jenjang pendidikan yang berbeda-beda, supaya bisa diketahui apakah media pembelajaran yang kita buat ini, dimana yang paling cocok untuk diterapkan pada jejang sekolah SMP, SMA atau Universitas? baik dari segi fitur maupun kontennya.

\section{METODE}

Metode yang digunakan untuk melaksanakan uji coba augmented reality dengan menggunakan visual WIKU ada 3 tahap, meliputi:

\section{Tahap 1 Menentukan Jenjang Sekolah}

Penetapan jejang sekolah ini didasarkan pada muatan media pembelajaran yang ada di augmented reality dengan menggunakan visual WIKU, yaitu mata pelajaran yang menerangkan struktur morfologi dari bunga Wijaya Kusuma. Dimulai dari bagian tangkai, kelopak, benang sari, putik sampai terjadinya penyerbukan. Dari hasil pertimbangan tersebut, maka ditetapkan tiga jenjang sekolah yaitu SMP, SMA dan S1 jurusan biologi sebagai sampel dari uji coba. Untuk memilih nama SMP, SMA dan S1 jurusan biologi nya dipilih secara random sampling (Hadi, 1986).

\section{Tahap 2 Membuat Kuisioner}

Kuisioner dibuat supaya dapat mengetahui respon dari siswa - siswa, untuk menilai augmented reality dengan menggunakan visual WIKU baik dari segi antarmuka aplikasi maupun konten aplikasi yang ada. Kuisioner divalidasikan kepada pihak yang berkompeten dalam bidangnya

\section{Tahap 3 Analisis Data}

Hasil dari data kuisioner dianalisa baik secara kuantitatif maupun kualitatif, guna mendapatkan jenjang sekolah yang mana yang tetap untuk menerapkan augmented reality dengan menggunakan visual WIKU ini.

\section{HASIL DAN PEMBAHASAN}

Menurut Ihsan (2011), tingkat pendidikan sekolah terdiri dari pendidikan dasar, pendidikan menengah dan pendidikan tinggi. Berdasarkan tingkatan pendidikan, akan mempengaruhi pendapat siswa terhadap konten yang akan diujikan. Seperti pendapat dari Carter (2011) bahwa semakin tinggi tingkat pendidikan seseorang akan semakin mudah menerima informasi sehingga semakin banyak pula pengalaman yang dimiliki dan pengetahuan yang luas tentang sesuatu hal. Penelitian ini menguji 2 konten yaitu a. Konten antarmuka aplikasi, b. Konten aplikasi.

\section{a. Antarmuka Aplikasi}

Hasil uji coba pada konten antarmuka aplikasi bisa dilihat pada gambar 1, pada pertanyaan ke 1. Apakah rancangan home screen sesuai dengan isi materi, 2. Apakah warna tombol bagus, 5. Bagaimana visualisasi model 3D, 6. Bagaimana realitas model yang ditampilkan, 8. Apakah intonasi suara narasi jelas, 9. Apakah suara musik latar terdengar jelas dan 10. Secara umum aplikasi mudah digunakan. Rata-rata 
jawaban yang diberikan untuk tingkat pendidikan SMP lebih tinggi dari pada SMA dan Universitas yaitu untuk pertanyaan no 1 . 4,4 , no 2 . 4,2 , no $5.4,0$, no. $6.4,15$, no. 8 . 4,25 , no. $9.3,85$ dan no. $10.4,35$.

Hal ini disebabkan siswa SMP dalam menerima penjelasan dari guru, diperhatikan dengan sungguh-sungguh dan memiliki pengetahuan yang masih terbatas, sehingga mereka menilai konten tersebut dengan nilai rata-rata 4 yaitu mudah/ bagus/ sesuai/ jelas Sedangkan pada pertanyaan ke 3 yaitu Apakah ukuran tombol sesuai, pertanyaan ke 4 yaitu Apakah penempatan tombol memudahkan penggunaan, pernyataan ke 7 yaitu Apakah narasi teks terbaca dengan mudah. Rata-rata jawaban siswa SMP lebih rendah dari siswa SMA, tetapi tetap lebih tinggi dari rata-rata yang diberikan oleh siswa universitas. Hal ini dikarenakan pada awal aplikasi dihidupkan perhatian siswa kurang terhadap ukuran dan penempatan tombol pada aplikasi tersebut, sedangkan pada pertanyaan ke 7 siswa SMP masih belum paham apa yang dimaksud dengan kata narasi pada pertanyaan tersebut.

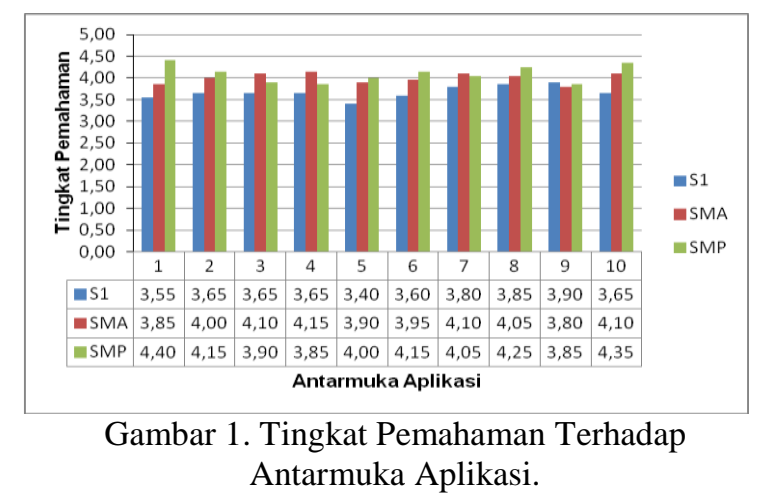

Pada tingkat pendidikan S1, untuk semua pertanyaan yang ada pada antarmuka aplikasi ini, hasil rata-ratanya mempunyai bobot 3 lebih, yang artinya netral, mereka tidak menilai bagus ataupun jelek. Hal ini menandakan bahwa pada tingkat pendidikan S1, menganggap visual WIKU ini biasabiasa saja, alasan ini bisa diterima karena materi pelajaran yang dia terima pada bangku kuliah lebih dari materi tersebut. Dan tidak memberi nilai jelek dengan alasan, mereka melihat apa yang disajikan pada visual WIKU bagus dan menarik untuk ditonton atau dilihat. Terbukti dari hasil ratarata pada pertanyan ke 8. Apakah intonasi suara narasi jelas dan pertanyan ke 9. Apakah suara musik latar terdengar jelas. Mereka berikan bobot 3,85 dan 3,90 (hampir mendekati bobot 4) yang artinya mereka mengakui intonasi suara narasi dan suara musik latar belakang menjadiakan visual WIKU mempunyai nilai bagus.

\section{b. Konten Aplikasi}

Hasil uji coba pada konten aplikasi dapat dilihat pada gambar 2, dengan pertanyaan ke 1 . Apakah narasi teks pada setiap scene sesuai dengan materi, 2. Apakah narasi suara sesuai dengan teks yang muncul di setiap scene, 3. Apakah narasi mudah dipahami, 5. Apakah suara latar mampu membangkitkan minat pengguna, dan petanyaan ke 7. Apakah secara umum aplikasi mampu eningkatkan pemahahanan terhadap materi belajar.

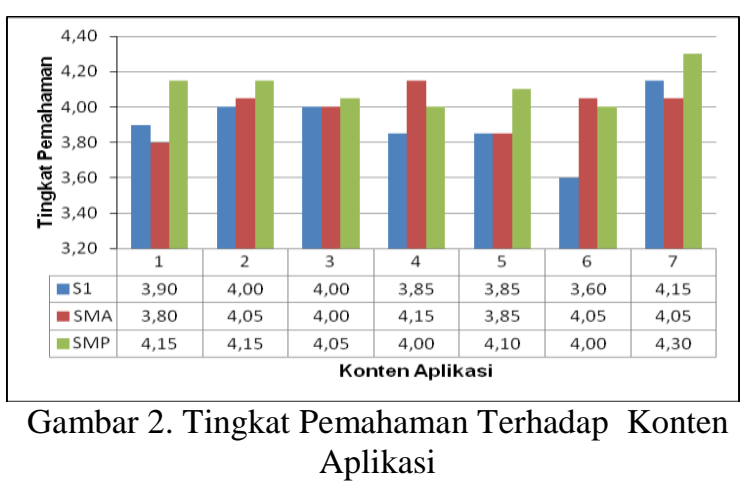

Rata-rata jawaban yang diberikan untuk tingkat pendidikan SMP lebih tinggi (yaitu mudah/bagus/sesuai/jelas, yang mempunyai bobot nilai 4) dari pada SMA dan Universitas yaitu untuk pertanyaan no $1.4,15$, no 2 . 4,15 , no 3. 4,1, no. 5. 4,10 dan no.7. 4,30. Hal ini disebabkan adanya ketertarikkannya siswa SMP terhadap isi kontek aplikasi yang menjelaskan bagian-bagian dari bunga wijaya kusuma sampai terjadinya perkawinan yaitu peristiwa bertemunya antara benang sari dengan kepala putik. Seperti sub bagian dari materi pelajaran yang mereka dapatkan.

Sedangkan pada pertanyaan ke 4 . Apakah narasi yang muncul sesuai dengan 
visualisasi, dan pertanyaan ke 6. Apakah response time aplikasi baik. Rata-rata jawaban anak SMP lebih rendah dari SMA dan Universitas. Rendahnya nilai jawabpan tersebut dikarekan adanya pengaruh tingkat pendidikan terhadap pemahanan tentang maksud suatu pertanyaan. Untuk pendidikan setingkat SMP pemahaman terhadap pertanyan mengalami sedikit kesulitan untuk mengartikannya. Oleh sebab itu diperlukan sedikit penjelasan, supaya jelas apa yang dimaksud oleh pertanyaan tersebut.

Eberhardt et al (2007) meneliti tentang latar belakang pendidikan yang dihubungkan dengan tingkat pengetahuan, menyatakan bahwa mereka yang berpendidikan dengan level lebih tinggi, memiliki tingkat pengetahuan lebih luas dan pengalaman yang banyak.

Yang menjadi perhatian dari jawaban pada konten aplikasi ini adalah pada pertanyaan ke 2. Apakah narasi suara sesuai dengan teks yang muncul di setiap scane, pertanyaan ke 3. Apakah narasi mudah dipahami dan pertanyaan ke 7. Apakah secara umum aplikasi mampu meningkatkan pemahanan terhadap materi belajar. Semua jenjang pendidikan menjawab rata-ratanya lebih dari 4. Hal ini menandakan bawah semua jenjang pendidikan mengakui dengan adanya penabahan narasi suara akan memperjelas dan mempermudah untuk memahami isi materi yang akan disampaikan lewat aplikasi tersebut.

\section{SIMPULAN}

Dari hasil penelitian ini dapat disimpulkan bahwa, dari dua komponen yang ditanyakan yaitu antarmuka dan konten aplikasi, hasil rata-rata jawaban pada tingkat pendidikan SMP yang memberikan bobot 4 , sedangkan tingkat pendidikan S1 rata-rata bobotnya 3 dan SMA antara bobot 3 dan 4 hampir seimbang. Dari hasil penjelasn ini dapat disimpulkan bahwa tingkat pendidikan SMP yang memberi nilai bagus pada visual WIKU, yang artinya visual WIKU bisa diterapkan pada tingkat pendidikan SMP.

\section{DAFTAR PUSTAKA}

Alex Medi Haryanto, Tonny Komputindo (2017). Aplikasi Augmented Reality Sebagai Media.

Carter, W. Disaster Manegement: A Disaster Manager's Handbook. Manila: ADB; 2011. 1-204

Chari, V. Singh, J.M., dan Narayanan, P.J. (2008). Augmented reality using.

Eberhardt, E., Bonzanigo, L., \& Loew, S. Long-term investigation of a deepseated creeping landslide in crystalline rock. Part II. Mitigation measures and numerical modelling of deep drainage at Campo Vallemaggia. Canadian Geotechnical Journal; 2007, 44 (10): 812

Haviluddin. Language., (2011). Jurnal Informatika Mulawarman Vol 6. 2011.

Pragestu, Steven. (2015). Implementasi Augmented Reality dengan alat indra.

Purnomo, Sudjino, Trijoko, Suwarno Hadisusanto. (2009). BIOLOGI. Aplikasi Augmented Reality. Jakarta: Intan Pariwara.

R. T. Azuma, "Survey of Augmented Reality," 1997.

S. Hadi, 1986 Metodologi Research, C.V. Rajawali.

Sukamto, Rosa Ariani dan M. Shalahudin. (2013). Rekayasa perangkat menarik minat siswa dengan memiki tampilan yang Lunak Terstruktur dan Berorientasi Objek. Bandung: Informatika.

Supardi, Yuniar. 2011. Semua Bisa Menjadi Programmer Android. visualisasi dari alat indra berbentuk animasi dan objek 3D.Jakarta:

Universitas Tanjungpura. Jurnal Edukasi dan Penelitian Informatika, memahami materi. Vol.1-2 h.8, Universitas Tanjungpura, Pontianak.

Zuma, Ronald T .(1997),, A survey of Augmented Reality. Presence 6.4 